\title{
FISH SPECIES INDICATORS OF ENVIRONMENTAL QUALITY OF NEOTROPICAL STREAMS IN SOUTHERN BRAZIL, UPPER PARANÁ RIVER BASIN
}

\author{
Dyego L. F. CAETANO ${ }^{1,2 *}$, Edson F. de OLIVEIRA³, and Cláudio H. ZAWADZKI ${ }^{4}$ \\ ${ }^{1}$ Grupo de Estudos e Pesquisa em Recursos Hídricos e Ecologia Aplicada (GEPRHEA), Universidade Estadual do \\ Norte do Paraná, Jacarezinho, Paraná, Brazil \\ ${ }^{2}$ Programa de Pós-Graduação em Biologia Comparada, Universidade Estadual de Maringá, Maringá, Paraná, Brazil \\ ${ }^{3}$ Laboratório de Ecologia Teórica e Aplicada, Universidade Tecnológica Federal do Paraná, Londrina, Paraná, Brazil \\ ${ }^{4}$ Núcleo de Pesquisas em Limnologia, Ictiologia e Aquicultura (Nupélia), Universidade Estadual de Maringá, Maringá, \\ Paraná, Brazil
}

Caetano D.L.F., Oliveira E.F., Zawadzki C.H. 2016. Fish species indicators of environmental variables of Neotropical streams in southern Brazil, upper Paraná River basin. Acta Ichthyol. Piscat. 46 (2): 87-96.

Background. Some studies in the Neotropical ecozone evaluated the correlation between the ichthyofauna and the physical and chemical characteristics of streams. This study aimed to estimate the environmental quality of Neotropical streams through quality protocols and diversity indexes. The hypothesis is that it is possible to identify fish species indicators of variables and streams quality associated to environmental conservation and degradation.

Materials and methods. Sampling occurred quarterly from October 2012 to July 2013, totalling four phases of field surveys in three sample units on each stream (Água dos Anjos Stream, Monjolinho Stream, and Ubá Stream, upper Paraná River basin) in southern Brazil. The Indicator Value Method (IndVal) was used to relate the ichthyofauna (abundance and relative frequency of fish species) to physical and chemical variables and streams and their respective environmental characteristics.

Results. A total of 33 species were analysed as possible indicators by the IndVal method, and 21 species showed a significant relation $(P<0.05)$ to one or more environmental variables. The exotic Poecilia reticulata Peters, 1859 was best linked to low-oxygen water. Bryconamericus iheringii (Boulenger, 1887) was an indicator of the stream with the worst environmental quality among the analysed streams, and also indicated significantly lower extent of riparian vegetation $(<6 \mathrm{~m})$ and unstable substrate. Geophagus brasiliensis (Quoy et Gaimard, 1824) was also indicator of the stream with inferior environmental quality and low of riparian vegetation $(<6 \mathrm{~m})$. On the other hand, Trichomycterus diabolus Bockmann, Casatti et de Pinna, 2004 was indicator of diverse habitat environments, as it was linked to higher extent of riparian vegetation $(>18 \mathrm{~m})$ and high water oxygenation.

Conclusion. The fish species: P. reticulata, B. iheringii, and G. brasiliensis were indicators of inferior environmental quality, and T. diabolus was an indicator of superior quality, and its abundance can characterize as important bio-indicators of environmental characteristics of Neotropical streams.

Keywords: fish conservation, Indicator Value Method, Neotropical fishes, environmental quality of streams

\section{INTRODUCTION}

Several studies dealing with the relation of fish communities to levels of environmental variables use indices of biotic integrity (Angermeier and Karr 1984, Casatti et al. 2006, Pinto and Araújo 2007, Machado et al. 2011). In the Neotropics some studies evaluated the correlation between the fish assemblages and the physical characteristics of streams, such as width, depth, type of substrate, flow (Araújo and Tejerina-Garro 2007, Felipe and Súarez 2010, Araújo et al. 2011), presence of the riparian vegetation (Casatti 2010), and the chemical properties of water (Silva 1995, Oliveira and Bennemann 2005, Daga et al. 2012). However, few studies have sought to identify species that directly express the current characteristics of the environment in which they operate, with indicator species index (Alexandre et al. 2010). 
Dufrene and Legendre (1997) proposed an index of indicator species evaluation called Indicator Value Method (IndVal), which takes into account values of abundance and frequency of occurrence of a species, and relating them to an environmental variable. According to McGeoch and Chown (1998), the IndVal has the advantages of robustness to compare data from different sample sizes and derived from different methodologies, and the fact that the groups, or categories, can be classified priori or posteriori, hierarchically or not, when it is compared to some others used to find indicator species.

The IndVal has been employed in studies with different organisms, from bacteria (Shawkey et al. 2009), plants (Bataineh et al. 2007), aquatic invertebrates (Carbonell et al. 2011, Souza et al. 2011), amphibians (Campos et al. 2013), birds (Mikusiński et al. 2001), and fish (Penczak 2009, Penczak et al. 2012, Dukowska et al. 2013).

Karr (1981) considers some advantages of using fish as indicator organisms in environmental monitoring programs: the large amount of information on the life history of many species of fish, the range of trophic levels, the relative easiness of identification, the relative knowledge of the general public to understand the results from scientific information about this group, the possibility of analysing the effects of toxicity and stress along fish growth and reproduction, and the presence of fishes in virtually all types of aquatic environments.

The hypothesis of this study is that it is possible to identify Neotropical fish species indicators of variables and streams associated to environmental conservation and degradation, detected by environmental protocols and ecological diversity indexes.

\section{MATERIALS AND METHODS}

Study area. The samplings were performed in the Das Cinzas River basin, located in southern Brazil, in the upper Paraná River system. The total area of the Das Cinzas River basin is $9612.8 \mathrm{~km}^{2}$ and its length is $240 \mathrm{~km}$. The region is composed by areas of artificial pasture, mixed plantations, grasslands, and forestry. The industries of the region are mainly agro-industrial, such as sugar mills, distilleries, dairies, and slaughterhouses (Pereira and Scroccaro 2015). The physical and chemical characteristics and the fishes were sampled in three streams of Atlantic Forest biome tributaries of the Jacarezinho River, located in the medium portion of the Das Cinzas River. The three streams are: Água dos Anjos Stream and Monjolinho Stream, tributaries of the right margin of the Jacarezinho River, and Ubá Stream, tributary of the left margin. Sampling occurred in three units on each stream-Água dos Anjos Stream: A1: headwater $\left(23^{\circ} 13^{\prime} 15.80^{\prime \prime} \mathrm{S}, 49^{\circ} 57^{\prime} 12.46^{\prime \prime} \mathrm{W}\right)$, A2: middle $\left(23^{\circ} 13^{\prime} 24.80^{\prime \prime} \mathrm{S}, 49^{\circ} 57^{\prime} 26.19^{\prime \prime} \mathrm{W}\right)$, A3: mouth $\left(23^{\circ} 13^{\prime} 39.60^{\prime \prime} \mathrm{S}, 4^{\circ} 58^{\prime} 32.11^{\prime \prime} \mathrm{W}\right)$; Monjolinho Stream: M1: headwater $\left(23^{\circ} 15^{\prime} 56.35^{\prime \prime} \mathrm{S}, 4^{\circ} 54^{\prime} 57.53^{\prime \prime} \mathrm{W}\right), \mathrm{M} 2$ : middle $\left(23^{\circ} 16^{\prime} 28.10^{\prime \prime} \mathrm{S}, 4^{\circ} 55^{\prime} 46.46^{\prime \prime} \mathrm{W}\right)$, M3: mouth $\left(23^{\circ} 16^{\prime} 25.46^{\prime \prime} \mathrm{S}, 4^{\circ} 56^{\prime} 42.01^{\prime \prime} \mathrm{W}\right)$; and Ubá Stream: $\mathrm{U} 1$ : headwater $\left(23^{\circ} 14^{\prime} 15.00^{\prime \prime} \mathrm{S}, 50^{\circ} 2^{\prime} 13.00^{\prime \prime} \mathrm{W}\right)$, U2: middle $\left(23^{\circ} 13^{\prime} 43.82^{\prime \prime} \mathrm{S}, 50^{\circ} 2^{\prime} 15.25^{\prime \prime} \mathrm{W}\right)$, U3: mouth $\left(23^{\circ} 12^{\prime} 59.76^{\prime \prime} \mathrm{S}, 50^{\circ} 2^{\prime} 8.85^{\prime \prime} \mathrm{W}\right)$ (Fig. 1). Each sample unit was represented by a stream stretch of $50 \mathrm{~m}$ length, previously blocked upstream and downstream with fence made of netting material of $3 \mathrm{~mm}$ mesh.

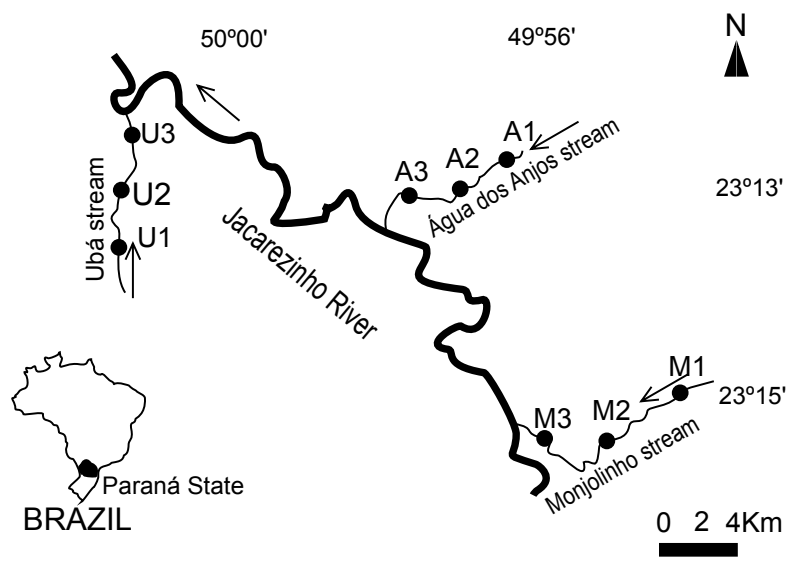

Fig. 1. Sampling units in streams Água dos Anjos, Monjolinho, and Ubá, Das Cinzas River basin, upper Paraná River, southern Brazil; The arrows indicate the direction of water flow

Abiotic variables and environmental quality. The physical and hydrological characteristics measured in each sampling section were: maximum width and depth of the channel, measured with a $10 \mathrm{~m}$ measuring tape, water velocity by the float method, flow (Palhares et al. 2007), and temperature (Tecnopon ${ }^{\circledR}$ MPA-210P). The chemical characteristics analysed were: conductivity (Instrutherm ${ }^{\circledR}$ CD-860), dissolved oxygen (Politerm ${ }^{\circledR}$ POL-60), and $\mathrm{pH}$ (Tecnopon ${ }^{\circledR}$ MPA-210P). Additionally, a protocol for visual assessment of habitats, modified from Callisto et al. (2001, Appendix A) was used. The protocol considered the properties of the aquatic ecosystems and margins, as substrates, changes in watercourses, presence and extent of riparian vegetation and margin stability. In this protocol, each environmental characteristic received scores from 0 to 3 , according to their quality ( 0 for minimum quality, and 3 for maximum quality). Each stream was classified as environment of superior or inferior quality (high and low values of the protocol summation, respectively). Moreover, parameters of richness, abundance, Pielou Equitability $\left(J^{\prime}\right)$ and Shannon diversity $\left(H^{\prime}\right)$ were estimated on fish populations. The results of the application of protocol on environmental assessment and of the diversity parameters were used to assess the environmental quality of streams, and later, to relate to their fish species indicators.

Fish collection. Sampling occurred quarterly from October 2012 to July 2013, totalling four phases of field surveys. Fish were collected by electrofishing with alternating current of $127 \mathrm{~V}$ and $6 \mathrm{~A}$. Three successive runs of dip nets in each stretch from downstream to upstream direction were performed. Captured individuals were anesthetized and sacrificed by immersion in eugenol (active ingredient: phenolic eugenol, 4-Allyl-2-methoxyphenol-C10H12O2, derived from stems, flowers, and leaves of Eugenia caryophyllata and Eugenia aromatica trees) (Griffiths 2000), fixed in $10 \%$ formalin solution and later preserved 
in $70 \%$ ethanol. The species identifications were performed according to Oyakawa et al. (2006) and Graça and Pavanelli (2007). Voucher species were deposited in the Ichthyological Collection of the Center of Research in Limnology, Ichthyology and Aquaculture (Nupélia) of the University of Maringá State.

Data analysis. Indicator Value Method (IndVal) (Dufrene and Legendre 1997) was used to relate the ichthyofauna (abundance and relative frequency of fish species) to: physical and chemical variables and environmental quality of the streams by modified from Callisto et al. (2001) (Appendix A). The physical and chemical variables and the streams (which were also considered variables) were classified into three categories (Table 1), related to the ecological parameters of environmental quality streams: category 1 for the lowest physical and chemical variables values and for the Água dos Anjos stream, category 2 for the median values and for the Monjolinho Stream, and category 3 for the high values and for the Ubá stream. Moreover, three environmental variables were selected from the modified protocol of Callisto et al. (2001). Each environmental variable was classified into four categories, ranging from 0 (inferior) to 3 (superior environmental quality; Table 2). The IndVal employs the Monte Carlo test with 5000 permutations, and significant values $(P<$ 0.05 ) were used to define potential indicator species of particular categories of the streams, physical and chemical variables and of the environmental characteristics. The formula of the IndVal is

$$
\operatorname{IndVal}_{i j}=A_{i j} \times B_{i j} \times 100
$$

where

$$
\begin{aligned}
& A_{i j}=n_{i j} \cdot n_{i}^{-1} \\
& B_{i j}=N_{i j} \cdot N_{i}^{-1}
\end{aligned}
$$

where: $A_{i j}$ is the mean abundance of $i$ species in $j$ category, $B_{i j}$ refers to the number of categories in the variable $j$ where the $i$ species is present, $n_{i j}$ is the number of individuals $j i, n_{i}$ is the number of individuals $i, N_{i j}$ is the number of sites $j i, N_{i}$ is the total number of categories of variable $i$. This analysis was performed using PC-ORD 3.0 program (McCune and Mefford 1997). Additionally, Spearman analysis was performed to evaluate the possible correlation between the values of physical and chemical variables to the ecological attributes of fish populations: richness, abundance, Pielou Equitability $\left(J^{\prime}\right)$ and Shannon Diversity $\left(H^{\prime}\right)$. We assume that when a species is an indicator of a type of physical or chemical variables related to low diversity, it could also be considered indicative of inferior environmental quality, which is also true in reverse. Correlation coefficients and diversity were calculated in the PAST program (Hammer et al. 2001), and the correlation graphs were performed in Statistica 7.1 (Statsoft).

\section{RESULTS}

A total of 7102 specimens of 33 species from six orders and 12 families were captured. In the protocol of environmental quality applied, the Ubá Stream scored the highest values $(\mathrm{U} 1=39, \mathrm{U} 2=28$, and $\mathrm{U} 3=27$ ), followed by Monjolinho Stream $(\mathrm{M} 1=20, \mathrm{M} 2=29$, and $\mathrm{M} 3=25)$, and by Água dos Anjos Stream $(\mathrm{A} 1=23, \mathrm{~A} 2=$ 13 , and A3 = 21). For the diversity, Ubá Stream showed the highest values in indices of Shannon $\left(H^{\prime}=2.053\right)$ and Pielou Equitability $\left(J^{\prime}=0.758\right)$. In turn, the Água dos Anjos Stream was pointed out as the least diverse $\left(H^{\prime}=1.942\right)$, due to high dominance $(D=0.2366)$, and the Monjolinho Stream was intermediary in diversity $\left(H^{\prime}=\right.$ $\left.2.006, J^{\prime}=0.6231, D=0.2188\right)$.

Concerning the IndVal index, of the 33 species analysed as possible indicators, 22 showed significant relation $(P=<0.05)$ to one or more categories, and eleven were not significantly related to any category of physical or chemistry variable, environmental characteristics or streams. The majority of species were related to four to six categories, each. The Água dos Anjos Stream showed the largest number of significant associations, revealing eleven indicator species to this environment, followed by the Monjolinho Stream with four, and the Ubá Stream, with only two (Table 3 ).

Table 1

\begin{tabular}{|c|c|c|c|}
\hline Variable & Category 1 & Category 2 & Category 3 \\
\hline Stream & Água dos Anjos & Monjolinho & Ubá \\
\hline Conductivity $\left[\mathrm{mS} \cdot \mathrm{cm}^{-1}\right]$ & $<0.20$ & $0.20-0.22$ & $>0.22$ \\
\hline Width $[\mathrm{m}]$ & $<4$ & 4-6 & $>6$ \\
\hline Oxygen $\left[\mathrm{mg} \cdot \mathrm{L}^{-1}\right]$ & $<13$ & $13-14$ & $>14$ \\
\hline $\mathrm{pH}$ & $<7.5$ & $7.5-8$ & $>8$ \\
\hline Depth $[\mathrm{cm}]$ & $<50$ & $50-60$ & $>60$ \\
\hline Temperature $\left[{ }^{\circ} \mathrm{C}\right]$ & $<22.7$ & $22.7-24$ & $>24$ \\
\hline Flow $\left[\mathrm{m}^{3} \cdot \mathrm{s}^{-1}\right]$ & $<0.20$ & $0.20-0.40$ & $>0.40$ \\
\hline Velocity $\left[\mathrm{m} \cdot \mathrm{s}^{-1}\right]$ & $<0.3$ & $0.3-0.4$ & $>0.4$ \\
\hline
\end{tabular}

Categories of streams and the physical and chemical variables used in the IndVal analysis with stream fishes of the Das Cinzas River basin, upper Paraná River

Category $1=$ low values, category $2=$ medium values, Category $3=$ high values. 
Table 2

Environmental categories (modified from Callisto et al. 2001) used in the IndVal analysis of stream fish of the Das Cinzas River basin, upper Paraná River

\begin{tabular}{|c|c|c|c|c|}
\hline Variable & Category 0 & Category 1 & Category 2 & Category 3 \\
\hline $\begin{array}{l}\text { Type of } \\
\text { substrate }\end{array}$ & $\begin{array}{l}\text { Rocky; absence of loose } \\
\text { stones }\end{array}$ & $\begin{array}{l}\text { Mainly formed of gravel; } \\
\text { presence of some loose stones }\end{array}$ & $\begin{array}{l}\text { Abundance of loose } \\
\text { stones and gravel }\end{array}$ & Abundance of loose stones \\
\hline $\begin{array}{l}\text { Type of stream } \\
\text { bottom }\end{array}$ & $\begin{array}{l}\text { Less than } 10 \% \text { stable } \\
\text { habitat; substrate unstable } \\
\text { or absent }\end{array}$ & $\begin{array}{l}10 \%-30 \% \text { of stable habitat; } \\
\text { substrates frequently modified }\end{array}$ & $\begin{array}{l}30 \%-50 \% \text { of stable } \\
\text { habitats, without } \\
\text { evidence of alteration by } \\
\text { erosion or siltation }\end{array}$ & $\begin{array}{l}\text { More than } 50 \% \text { of stable } \\
\text { and diversified habitats } \\
\text { (pieces of submerged } \\
\text { trunks, gravel) }\end{array}$ \\
\hline $\begin{array}{l}\text { Riparian } \\
\text { vegetation }\end{array}$ & $\begin{array}{l}\text { Width of riparian vegetation } \\
\text { less than } 6 \mathrm{~m} \text {; restricted } \\
\text { or no vegetation due to } \\
\text { anthropogenic activity } \\
\text { (pastures, roads, etc.) }\end{array}$ & $\begin{array}{l}\text { Width of riparian vegetation } \\
\text { between } 6 \text { and } 12 \mathrm{~m} \text {; intense } \\
\text { anthropogenic activity }\end{array}$ & $\begin{array}{l}\text { Width of riparian } \\
\text { vegetation between } \\
12 \text { and } 18 \mathrm{~m} \text {; minimal } \\
\text { anthropogenic activity }\end{array}$ & $\begin{array}{l}\text { Width of riparian } \\
\text { vegetation }>18 \mathrm{~m} \text {; } \\
\text { without influence of } \\
\text { anthropogenic activities }\end{array}$ \\
\hline
\end{tabular}

Category $0=$ characteristics of inferior environmental quality, Category $3=$ characteristics of superior environmental quality.

Geophagus brasiliensis (Quoy et Gaimard, 1824); Crenicichla britskii Kullander, 1982; and Oligosarcus paranensis Menezes et Géry, 1983 were the best quality indicators (species with higher IndVal values associated with this stream) of the Água dos Anjos Stream, whereas Apareiodon piracicabae (Eigenmann, 1907); Apareiodon ibitiensis Amaral Campos, 1944; and Hypostomus hermanni (Ihering, 1905) had the highest significant values for the Monjolinho Stream, and finally, Trichomycterus diabolus Bockmann, Casatti et de Pinna, 2004 and Imparfinis mirini Haseman, 1911 were unique indicators to the Ubá Stream (Table 3). Trichomycterus diabolus and Serrapinnus notomelas (Eigenmann, 1915) showed significant associations with the largest number of environmental variables (eleven and nine, respectively), and T. diabolus was the best indicator to four categories: smaller width, depth and temperature and high dissolved oxygen. In addition, $T$. diabolus was also the best indicator of environments with abundance of loose stones, diverse habitats and high amount of riparian vegetation (width $>18$ $\mathrm{m})$. Apareiodon piracicabae and Poecilia reticulata Peters, 1859 were the best indicators to four and three extreme categories respectively. Apareiodon piracicabae indicated highest values of conductivity, width, temperature, and $\mathrm{pH}$, and $P$. reticulata indicated high water speed and high water depth, and low dissolved oxygen.

The species Characidium zebra Eigenmann, 1909, Imparfinis mirini, and Phalloceros harpagos Lucinda, 2008 had the highest values for two categories each: higher flow and engineered substrates for C. zebra, lower $\mathrm{pH}$ and conductivity for I. mirini, and less flow and low amount of riparian vegetation (width $<6 \mathrm{~m}$ ) for $P$. harpagos. Finally, the species with the largest indicator value for only one extreme category in the environmental variables were: Bryconamericus iheringii (Boulenger, 1887) for environment with rocky substrate and absence of rubble; G. brasiliensis for abundance of loose stones; Hypostomus strigaticeps (Regan, 1908) for 30\%-50\% of stable habitats; and Rhamdia quelen (Quoy et Gaimard, 1824) associated with low water velocity (Table 3 ). The hydrological variable with highest amount of species significantly associated was the water flow, with 14 associations, seven species were related to the high water flow (category 3), two to the middle (category 2) and five to the low flow (category 1). It was followed by variable river width with 13 associations, and $\mathrm{pH}$ with 11 .

Moreover, the depth and the substrate type showed a significant relation with only three species each. Two species were related to the high water depth and one to the low depth, whereas two species were related to abundance of loose stones and gravel, and one to abundance of loose stones. Riparian vegetation showed seven species with significant association values of their categories, and width, $\mathrm{pH}$ and temperature showed nine.

The Spearman analysis revealed a positive correlation between richness and conductivity $(r=0.78, P=0.02)$, conductivity and abundance $(r=0.77, P=0.02)$, water flow and diversity $(r=0.68, P=0.05)$ and abundance and richness $(r=0.78, P=0.02)$, and negative correlation between abundance and equitability $(r=-0.89, P=0.001$, Fig. 2).

\section{DISCUSSION}

The Água dos Anjos Stream was characterized by lower values in the diversity and in the protocol of quality environmental. This stream showed the worst environmental quality among the three studied streams, with lower equitability and higher dominance, which is typical features of impacted environments. Moreover, the Ubá Stream had the best quality, with higher values of diversity and equitability.

The main factor responsible for Geophagus brasiliensis as the best indicator of the Água dos Anjos Stream was its high abundance in this environment, and low abundance in the other sampled streams. In addition, the Água dos Anjos Stream was the only with a species of the order Perciformes as the main indicator. The parodontids Apareiodon piracicabae and $A$. ibitiensis were the best indicators of the Monjolinho Stream, with the former species also presenting the highest values for high conductivity, width, 

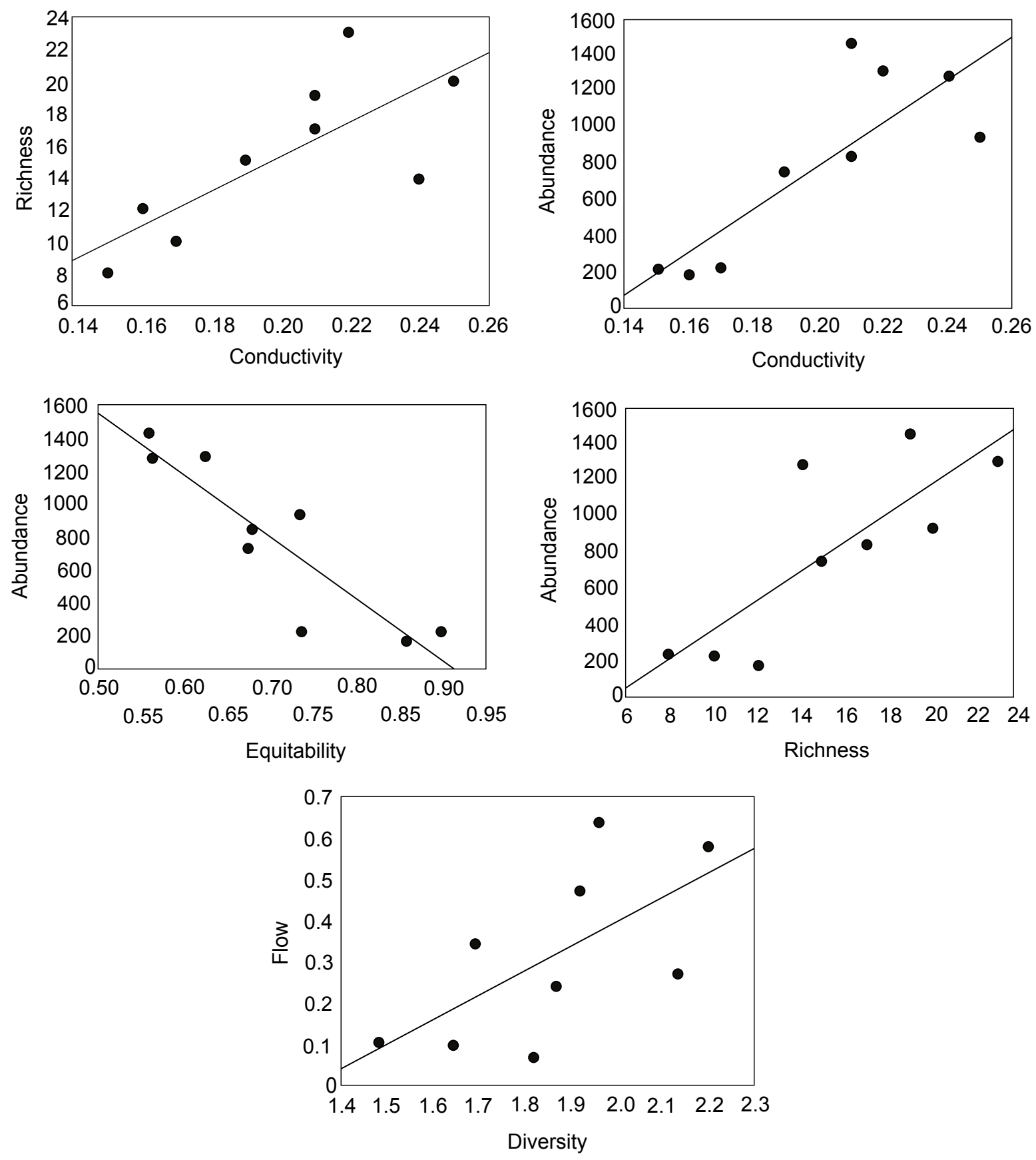

Fig. 2. Significant correlations (Spearman) between the ecological attributes of the fish fauna (richness, abundance, equitability $J^{\prime}$ and diversity $H^{\prime}$ ) and environmental variables

temperature and $\mathrm{pH}$. In turn, the Ubá Stream had two catfish (Siluriformes) as indicators, Trichomycterus diabolus and Imparfinis mirini. Trichomycterus diabolus was also associated with low temperatures, high dissolved oxygen, extensive cover of riparian vegetation (riparian vegetation width greater than $18 \mathrm{~m}$ ) and high habitat diversity (pieces of submerged trunks, gravel). Thus, these two species, particularly $T$. diabolus, were considered dependent to factors as habitat integrity, the integrity of the substrate, oxygenation and water quality (Casatti 2002, Shibatta and Cheida 2003, Oliveira and Bennemann 2005).

Among the species considered tolerant to environmental degradation, Phalloceros harpagos can be regarded as a model species, because it was associated with low flow and low riparian vegetation $(<6 \mathrm{~m})$. The absence of native riparian vegetation typically is associated to inferior environmental quality in streams of the Atlantic Forest biome (Casatti 2010). Geophagus brasiliensis and Bryconamericus iheringii were also significantly associated with lower extent of riparian vegetation. Casatti (2010) refers to the native riparian vegetation as an essential resource for maintaining the diversity of fish, relating the decrease in forest with species loss, faunal homogenization, and biomass reduction of these organisms. 


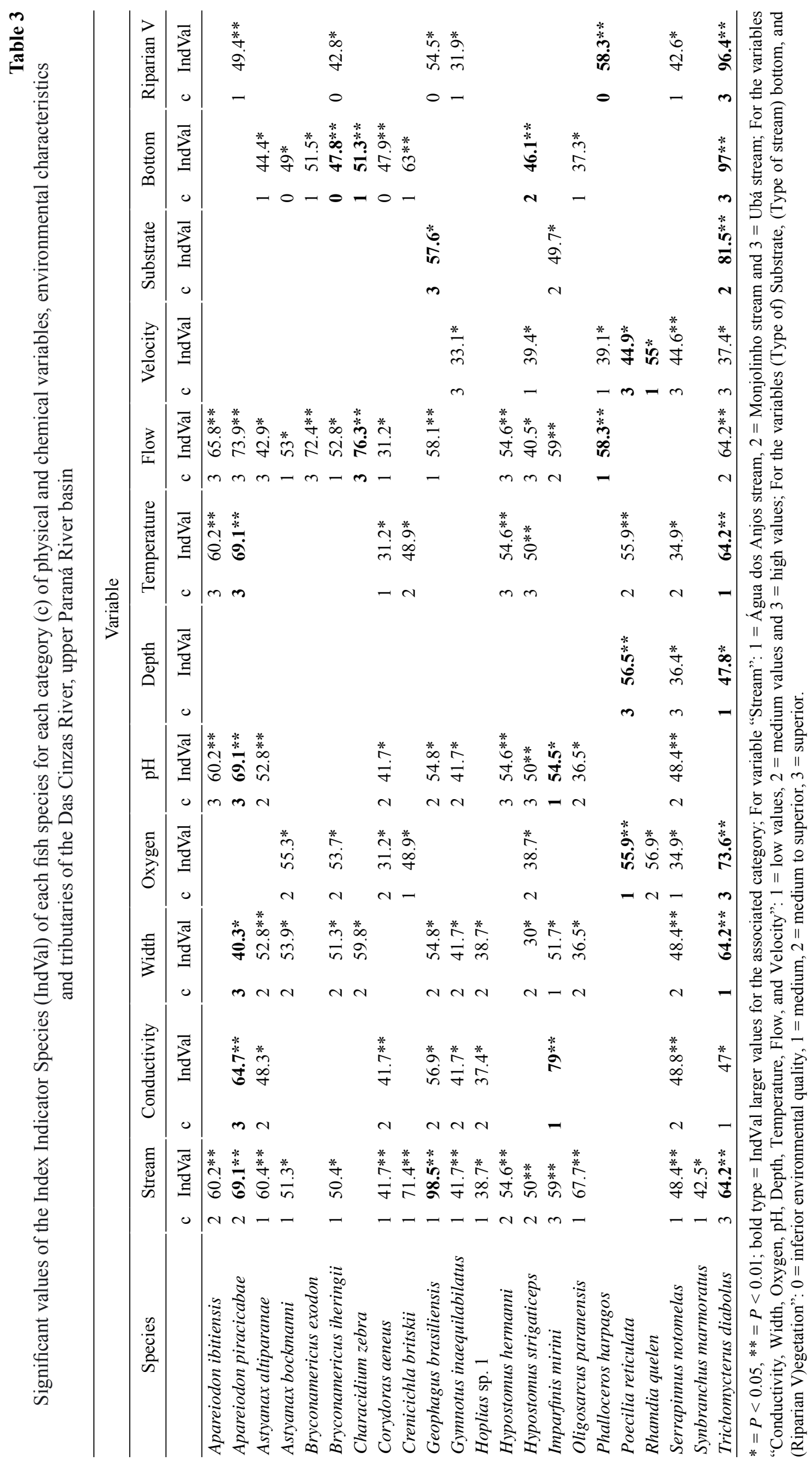


The association of Poecilia reticulata with the low oxygen level can be explained by the fact that this species have the ability to perform air-water interface respiration, for such environments with hypoxia (Kramer and Mehegan 1981). Poecilia reticulata is an exotic species introduced in the upper Paraná River basin in order to combat insect larvae (Langeani et al. 2007), and this fish is constantly linked to degraded environments, as in the work of Oliveira and Bennemann (2005), Pinto and Araújo (2007) and Vieira and Shibatta (2007). Ferreira and Casatti (2006) used $P$. reticulata in the construction of an Index of Biotic Integrity (IBI) correlating the increase in the percentage of its abundance with increasing degradation of habitats.

Characidium zebra was linked to higher flow, which was a characteristic of environments with higher diversity, but also indicated river bottoms with unstable substrates. According to Casatti and Castro (1998), C. zebra inhabits environments with relatively high water flow, as inferred from its fusiform body (Casatti and Castro 2006). The occurrence of Trichomycterus diabolus indicates low conductivity (characteristic of the Ubá Stream) and superior environmental quality, whose $T$. diabolus was also the best indicator. Usually in rivers and streams as those from the Atlantic Semideciduous Forest in southern Brazil, high conductivity may indicate inferior environmental quality, because as the conductivity measures the concentration of ions, high values may be the result of dumping of organic waste, leading to a decrease in oxygen and consequent homogenization of aquatic communities (Felipe and Súarez 2010).

The fact that $60 \%$ of the species analysed in this work as a possible indicator presented significant associations with at least one environmental categories, was primarily due to the use of a lot of variables for the Indicator Species Index, because each variable had a mean value of 8.9 significant interactions. This approach provides knowledge on the relation of fish species with a wider range of environmental characteristics. However, it is necessary to exercise caution at the time of classifying species as indicators of environmental degradation or conservation, because the same species can be relate to categories of both types of habitats. Even considering these practical difficulties, it was possible to diagnose, Poecilia reticulata, Bryconamericus iheringii, and Geophagus brasiliensis as tolerant to environmental degradation. The first two species were related to characteristics of low environmental quality. In addition, B. iheringii was abundant along all study sites, which proves its tolerance to different environmental characteristics. Geophagus brasiliensis, highly abundant in the Água dos Anjos Stream, indicated significantly well this stream with lower environmental quality. Teresa and Casatti (2012) also reported the highest frequency of $G$. brasiliensis to deforested streams, and Shibatta et al. (2002) and Castro (unpublished*) classified B. iheringii as constant in several different types of stream environments, inferring his tendency to generalize in the use of resources. Moreover, Trichomycterus diabolus may be considered indicative of good environmental quality to all studied streams, mainly to be linked to large amount of riparian vegetation (extension $>18 \mathrm{~m}$ ) and high habitat diversity (pieces of submerged trunks, gravel). Works such as those of Trajano (1997), Oliveira and Bennemann (2005), Galves et al. (2007), and Rondineli et al. (2009) considered the species of the genus Trichomycterus as sensitive to environmental degradation and argued that they can be used as indicators of superior environmental quality in Neotropical streams. Therefore, this paper gives knowledge into the monitoring and conservation of aquatic ecosystems through the use of stream fish species as important bioindicators of environmental characteristics.

\section{ACKNOWLEDGEMENTS}

The authors would like to thank: members of the Grupo de Estudos e Pesquisa em Recursos Hídricos e Ecologia Aplicada (GEPRHEA), of the Universidade Estadual do Norte do Paraná (UENP), for technical, logistical and financial supports for data collection; Núcleo de Pesquisas em Limnologia, Ictiologia e Aquicutura (NUPÉLIA) for logistical support for data collection and for help in identifying specimens; Laboratório de Ecologia Teórica e Aplicada, of the Universidade Tecnológica Federal Paraná/Câmpus Londrina, for equipment support; Coordination for the Improvement of Higher Level Education Personnel (CAPES) for scholarship and financial support, through the Programa de Pós-Graduação em Biologia Evolutiva, Universidade Estadual do CentroOeste; and the Chico Mendes Institute for Biodiversity Conservation (ICMBio / IBAMA) by fishing license number 30357-3.

\section{REFERENCES}

Alexandre C.V., Esteves K.E., Moura e Melo M.A.M. 2010. Analysis of fish communities along a rural-urban gradient in a Neotropical stream (Piracicaba River Basin, São Paulo, Brazil). Hydrobiologia 641: 97-114.

DOI: $10.1007 / \mathrm{s} 10750-009-0060-\mathrm{y}$

Angermeier P.L., Karr J.R. 1984. Relationships between woody debris and fish habitat in a small warmwater stream. Transactions of the American Fisheries Society 113: $716-726$.

DOI: 10.1577/1548-8659(1984)113<716:RBWDAF>2.0.CO;

Araújo M.I., Delariva R.L., Bonato K.O., Silva J.C. 2011. Fishes in first order stream in Ivaí River drainage basin, upper Paraná River Basin, Paraná State, Brazil. Check List 7 (6): 774-777.

Araújo N.B., Tejerina-Garro F.L. 2007. Fish diversity and composition in Cerrado streams, Ribeirão Ouvidor

* Castro R.J. 2003. Regime alimentar e ecomorfologia das espécies de peixes dominantes de um afluente do reservatório de Jurumirim (alto rio Paranapanema, São Pau1o). [Diet and ecomorphology of the dominant fish species in a tributary of Jurumirim Reservoir (upper Paranapanema River, São Paulo).] Tese (Doutorado), Universidade Estadual Paulista, Brasil. [In Portuguese.] 
basin, upper Paraná River basin, Goiás, Brazil. Revista Brasileira de Zoologia 24 (4): 981-990.

DOI: $10.1590 / \mathrm{S} 0101-81752007000400014$

Bataineh M.M., Oswald B.P., Bataineh A.L., Farrish K.W., Coble D.W., Edminster C.B. 2007. Plant communities associated with Pinus ponderosa forests in the Sky Islands of the Davis Mountains, Texas. Journal of the Torrey Botanical Society 134: 468-78.

Callisto M., Moretti M., Goulart M. 2001. Macroinvertebrados bentônicos como ferramenta para avaliar a saúde de riachos. [Benthic macroinvertebrates as a tool to assess the health of streams.] Revista Brasileira de Recursos Hídricos 6 (1): 71-82. [In Portuguese.]

Campos V.A., Oda F.H., Juen L., Barth A., Dartora A. 2013. Composition and species richness of anuran amphibians in three different habitat in an agrosystem in Central Brazilian Cerrado. Biota Neotropica 13 (1): 124-132.

DOI: $10.1590 / \mathrm{S} 1676-06032013000100014$

Carbonell J.A., Gutiérrez-Cánovas C., Bruno D., Abellán P., Velasco J., Millán A. 2011. Ecological factors determining the distribution and assemblages of the aquatic Hemiptera (Gerromorpha \& Nepomorpha) in the Segura River basin (Spain). Limnetica 30 (1): 59-70.

Casatti L. 2002. Alimentação dos peixes em um riacho do parque estadual Morro do Diabo, bacia do Alto rio Paraná, sudeste do Brasil. [Fish diet in a stream in the Morro do Diabo State Park, upper Paraná River basin, south-eastern Brazil.] Biota Neotropica 2 (2): 1-14. [In Portuguese.] DOI: 10.1590/S167606032002000200012

Casatti L. 2010. Alterações no Código Florestal Brasileiro: impactos potenciais sobre a ictiofauna. [Changes in the Brazilian Forest Code: potential impacts on fish populations.] Biota Neotropica 10 (4): 31-34. [In Portuguese.] DOI: 10.1590/S167606032010000400002

Casatti L., Castro R.M.C. 1998. A fish community of the São Francisco River headwaters riffles, southeastern Brazil. Ichthyological Exploration of Freshwaters 9: 229-242.

Casatti L., Castro R.M.C. 2006. Testing the ecomorphological hypothesis in a headwater riffles fish assemblage of the rio São Francisco, southeastern Brazil. Neotropical Ichthyology 4 (2): 203-214. DOI: $10.1590 /$ S1679-62252006000200006

Casatti L., Langeani F., Silva A.M., Castro R.M.C. 2006. Stream fish, water and habitat quality in a pasture dominated basin, southeastern Brazil. Brazilian Journal of Biology 66 (2): 681-696. DOI: $0.1590 /$ S1519-69842006000400012

Daga V.S., Gubiani E.A., Baumgartner G. 2012. Effects of abiotic variables on the distribution of fish assemblages in streams with different anthropogenic activities in southern Brazil. Neotropical Ichthyology 10 (3): 643-652.

DOI: $10.1590 / \mathrm{S} 1679-62252012000300018$
Dufrene M., Legendre P. 1997. Species assemblages and indicator species: The need for a flexible asymmetrical approach. Ecological Monographs 67 (3): 345-366. DOI: 10.1890/0012-9615(1997)067[0345:SAAIST]2.0.CO;2

Dukowska M., Grzybkowska M., Kruk A., Szczerkowska-Majchrzak E. 2013. Food niche partitioning between perch and ruffe: Combined use of a self-organising map and the IndVal index for analysing fish diet. Ecological Modelling 265: 221-229.

DOI: 10.1016/j.ecolmodel.2013.06.022

Felipe T.R.A., Súarez Y.R. 2010. Influência dos fatores ambientais nas comunidades de peixes de riachos em duas microbacias urbanas, Alto Rio Paraná. [Influence of environmental factors in stream fish communities in two urban watersheds, upper Paraná River.] Biota Neotropica 10 (2): 143-151. [In Portuguese.]

Ferreira C.P., Casatti L. 2006. Stream biotic integrity assessed by fish assemblages in the Upper Rio Paraná basin. Biota Neotropica 6 (3): 1-25. 10.1590/S167606032006000300002

Galves W., Jerep F.C., Shibatta A.O. 2007. Estudo da condição ambiental pelo levantamento de três riachos na região do Parque Estadual Mata dos Godoy (PEMG), Londrina, Paraná, Brasil. [Environmental condition study through macrofauna survey of three streams around Parque Estadual Mata dos Godoy (PEMG), Londrina, PR, Brazil.] Pan-American Journal of Aquatic Sciences 2 (1): 55-65. [In Portuguese.]

Graça W.J., Pavanelli C.S. 2007. Peixes da planície de inundação do alto rio Paraná e áreas adjacentes. [Fish of the Upper Paraná River floodplain and adjacent areas.] Eduem, Maringá. [In Portuguese.]

Griffiths S.P. 2000. The use of clove oil as an anesthetic and method for sampling intertidal rockpool fishes. Journal of Fish Biology 57 (6): 1453-1464. DOI: $10.1111 /$ j.1095-8649.2000.tb02224.x

Hammer O., Harper D.A.T., Ryan P.D. 2001. PAST: Paleontological statistics software package for education and data analysis. Palaeontologia Electronica 4 (1): 9pp.

Karr J.R. 1981. Assessment of biotic integrity using fish communities. Fisheries 6 (6): 21-27.

DOI: 10.1577/1548-8446(1981)006<0021:AOBIUF $>2.0 . C O ; 2$

Kramer D.L., Mehegan J.P. 1981. Aquatic surface respiration, an adaptive response to hypoxia in the guppy, Poecilia reticulata (Pisces, Poeciliidae). Environmental Biology of Fishes 6 (3-4): 299-313. DOI: $10.1007 / \mathrm{BF} 00005759$

Langeani F., Castro R.M.C., Oyakawa O.T., Shibatta O.A., Pavanelli C.S., Casatti L. 2007. Diversidade da ictiofauna do Alto Rio Paraná: composição atual e perspectivas futuras. [Diversity in the Upper Paraná River ichthyofauna: present composition and future prospects.] Biota Neotropica 5 (1): 181-197. [In Portuguese.] DOI: 10.1590/S167606032007000300020

Machado N.G., Venticinque E.M., Penha J. 2011. Effect of environmental quality and mesohabitat structure on a Biotic Integrity Index based on fish assemblages 
of cerrado streams from Rio Cuiabá basin. Brazilian Journal of Biology 71 (3): 577-586.

DOI: $10.1590 / \mathrm{S} 1519-69842011000400002$

McCune B., Mefford M.J. 1997. PC-ORD. Multivariate analysis of ecological data. Version 3,0. MjM Software. Oregon, Gleneden Beach.

McGeoch M.A., Chown S.L. 1998. Scaling up the value of bioindicators. Trends in Ecology and Evolution 13: 46-47.

DOI: $10.1016 / \mathrm{S} 0169-5347(97) 01279-2$

Mikusiński G., Gromadzki M., Chylarecki P. 2001. Woodpeckers as indicators of forest bird diversity. Conservation Biology 15: 208-217.

Oliveira D.C., Bennemann S.T. 2005. Ictiofauna, recursos alimentares e relações com as interferências antrópicas em um riacho urbano no sul do Brasil. [Ichthyofauna, food resources, and relations with anthropogenic interference in an urban stream in southern Brazil.] Biota Neotropica 5 (1): 95-107. [In Portuguese.] DOI: $10.1590 / \mathrm{S} 1676-06032005000100011$

Oyakawa O.T., Akama A., Mautari K.C., Nolasco J.C. 2006. Peixes de riachos da Mata Atlântica. [Stream fishes of the Atlantic Forest.] Neotropica, São Paulo. [In Portuguese.]

Palhares J.C.P., Ramos C., Klein J.B., Lima J.M.M., Muller S., Cestonaro T. 2007. Medição da Vazão em Rios pelo Método do Flutuador. Comunicado Técnico Embrapa. [In Portuguese.]

Penczak T. 2009. Fish assemblage compositions after implementation of the IndVal method on the Narew River system. Ecological Modelling 220: 419-423.

DOI: $10.1016 /$ j.ecolmodel.2008.11.005

Penczak T., Glowacki L., Kruk A., Galicka W. 2012. Implementation of a self-organizing map for investigation of impoundment impact on fish assemblages in a large, lowland river: Long-term study. Ecological Modelling 227: 64-71.

DOI: $10.1016 /$ j.ecolmodel.2011.12.006

Pereira M.C.B., Scroccaro J.L. 2015. Bacias Hidrográficas do Paraná: série histórica. [Parana River Basin: historical series.] 2 edn. Secretaria de Estado do Meio Ambiente e Recursos Hídricos do estado do Paraná. [In Portuguese.]

Pinto B.C.T., Araújo F.F.G. 2007. Assessing of biotic integrity of the fish community in a heavily impacted segment of a tropical river in Brazil. Brazilian Archives of Biology and Technology 50 (3): 489-502.

DOI: $10.1590 / \mathrm{S} 1516-89132007000300015$

Rondineli G.R., Caramassi A.L., Braga F.M. 2009. Population biology of Trichomycterus sp. (Siluriformes, Trichomycteridae) in Passa Cinco Stream, Corumbataí River sub-basin, São Paulo State, southeastern Brazil. Brazilian Journal of Biology 69 (3): 925-934.

DOI: $10.1590 / \mathrm{S} 1519-69842009000400022$
Shawkey M.D., Firestone M.K., Brodie E.L., Beissinger S.R. 2009. Avian incubation inhibits growth and diversification of bacterial assemblages on eggs. PLoS ONE 4 (2): e4522.

DOI: $10.1371 /$ journal.pone.0004522

Shibatta O.A., Cheida C.C. 2003. Composição em tamanho dos peixes (Actinopterygii, Teleostei) de ribeirões da bacia do rio Tibagi, Paraná, Brasil. [Composition in size of fishes (Actinopterygii, Teleostei) from streams of rio Tibagi basin, Paraná, Brazil.] Revista Brasileira de Zoologia 20 (3): 469-473. [In Portuguese.] DOI: 10.1590/S010181752003000300016

Shibatta O.A., Orsi M.L., Bennemann S.T., SilvaSouza A.T. 2002. Diversidade e distribuição de peixes na bacia do rio Tibagi. [Diversity and distribution of fish in the Tibagi River basin.] Pp. 403-424. In: Medri M.E., Bianchini E., Shibatta O.A., Pimenta J.A. (eds.) A bacia do rio Tibagi. [The basin of the Tibagi River.] UEL, Londrina. [In Portuguese.]

Silva C.P.D. 1995. Community structure of in urban and natural streams in the Central Amazon. Amazoniana, 8 (3-4): 221-236. DOI: $0.1590 / \mathrm{S} 0101-81752002000300026$

Souza H.M.L., Cabette H.S.R., Juen H. 2011. Baetidae (Insecta, Ephemeroptera) em córregos do cerrado matogrossense sob diferentes níveis de preservação ambiental. [Baetidae (Insecta, Ephemeroptera) of Cerrado streams in the state of Mato Grosso, Brazil, under different levels of environmental preservation.] Iheringia Série Zoologia 101 (3): 181-190. [In Portuguese.] DOI: 10.1590/S007347212011000200005

Teresa F.B., Casatti L. 2012. Influence of forest cover and mesohabitat types on functional and taxonomic diversity of fish communities in Neotropical lowland streams. Ecology of Freshwater Fish 21: 433-442.

DOI: $10.1111 /$ j.1600-0633.2012.00562.x

Trajano E. 1997. Population ecology of Trichomycterus itacarambiensis, a cave catfish from eastern Brazil (Siluriformes, Trichomycteridae). Environmental Biology of Fishes 50: 357-369.

DOI: $10.1023 / \mathrm{A}: 1007366119261$

Vieira D.B., Shibatta O.A. 2007. Peixes como indicadores da qualidade ambiental do ribeirão Esperança, município de Londrina, Paraná, Brasil. [Fishes as indicators of environmental quality of the Esperança River, Londrina municipality, Paraná, Brazil.] Biota Neotropica 7 (1): 57-65. [In Portuguese.] DOI: $10.1590 /$ S1676-06032007000100008

Received: 20 March 2016

Accepted: 19 June 2016

Published electronically: 30 June 2016 
Appendix A

Environmental assessment protocol applied in this study, to verify the environmental quality of the streams studied (modified from Callisto et al. 2001)

\begin{tabular}{|c|c|c|c|c|}
\hline Habitat parameters & $\begin{array}{c}\text { Great } \\
\text { (3 points) }\end{array}$ & $\begin{array}{c}\text { Good } \\
\text { (2 points) }\end{array}$ & $\begin{array}{l}\text { Median } \\
(1 \text { point })\end{array}$ & $\begin{array}{c}\text { Poor } \\
\text { (0 points) }\end{array}$ \\
\hline Fund type & $\begin{array}{l}\text { More than } 50 \% \text { of stable } \\
\text { and diversified habitats } \\
\text { (pieces of submerged } \\
\text { trunks, gravel) }\end{array}$ & $\begin{array}{l}30 \%-50 \% \text { of stable } \\
\text { habitats, without } \\
\text { evidence of alteration by } \\
\text { erosion or siltation }\end{array}$ & $\begin{array}{l}10 \%-30 \% \text { of stable } \\
\text { habitat; substrates } \\
\text { frequently modified }\end{array}$ & $\begin{array}{l}\text { Less than } 10 \% \text { stable } \\
\text { habitat; substrate unstable } \\
\text { or absent }\end{array}$ \\
\hline Pool width & $\begin{array}{l}\text { Rapids (Riffles) and } \\
\text { pools well developed; } \\
\text { pool as wide as the } \\
\text { stream, and with a length } \\
\text { equal to twice the width } \\
\text { of the stream }\end{array}$ & $\begin{array}{l}\text { Pools with the width of } \\
\text { the stream, but less than } \\
\text { twice the width of the } \\
\text { stream length }\end{array}$ & $\begin{array}{l}\text { Rapids absent; Pools not } \\
\text { as wide as the stream and } \\
\text { its length less than twice } \\
\text { the width of the stream }\end{array}$ & $\begin{array}{l}\text { Pools rapid or non- } \\
\text { existent }\end{array}$ \\
\hline Pool frequency & $\begin{array}{l}\text { Pools frequent; Pool } \\
\text { distance divided by } \\
\text { the width of the stream } \\
\text { between } 5 \text { and } 7\end{array}$ & $\begin{array}{l}\text { Pool infrequent; } \\
\text { remaining distance } \\
\text { divided by the width } \\
\text { of the river between } 7 \\
\text { and } 15\end{array}$ & $\begin{array}{l}\text { Pools or curves } \\
\text { occasional; habitats } \\
\text { formed by the contours of } \\
\text { the fund; distance between } \\
\text { pools divided by the width } \\
\text { of the stream between } 15 \\
\text { and } 25\end{array}$ & $\begin{array}{l}\text { Pools shallow or absent; } \\
\text { distance between pools } \\
\text { divided by the width of } \\
\text { the stream }>25\end{array}$ \\
\hline Substrate type & Abundance of rubbles & $\begin{array}{l}\text { Abundance of rubbles } \\
\text { and gravel }\end{array}$ & $\begin{array}{l}\text { Mainly formed of gravel; } \\
\text { presence of some rubbles }\end{array}$ & Rocky; absence of rubbles \\
\hline Deposition of mud & $\begin{array}{l}\text { Between } 0 \% \text { and } 25 \% \\
\text { of the fund covered with } \\
\text { mud (silt and clay) }\end{array}$ & $\begin{array}{l}\text { Between } 25 \% \text { and } 50 \% \\
\text { of the fund covered with } \\
\text { mud }\end{array}$ & $\begin{array}{l}\text { Between } 50 \% \text { and } 75 \% \text { of } \\
\text { the fund covered with mud }\end{array}$ & $\begin{array}{l}\text { Over } 75 \% \text { of the fund } \\
\text { covered by mud }\end{array}$ \\
\hline $\begin{array}{l}\text { Deposition of } \\
\text { sediments }\end{array}$ & $\begin{array}{l}\text { Less than } 5 \% \text { of the } \\
\text { fund with deposition of } \\
\text { sediments; absence of } \\
\text { deposition in the pools }\end{array}$ & $\begin{array}{l}\text { Some evidence } \\
\text { of change in the } \\
\text { background; increase } \\
\text { mainly gravel, sand } \\
\text { or mud; } 5 \%-30 \% \text { of } \\
\text { the modified fund, soft } \\
\text { deposition in the pools }\end{array}$ & $\begin{array}{l}\text { Moderate deposition of } \\
\text { gravel, sand or mud on } \\
\text { the margins, between } 30 \% \\
\text { and } 50 \% \text { of the modified } \\
\text { fund; moderate deposition } \\
\text { in the pools }\end{array}$ & $\begin{array}{l}\text { Large deposits of mud, } \\
\text { silted margins; more than } \\
50 \% \text { of the modified fund }\end{array}$ \\
\hline $\begin{array}{l}\text { Changes in the } \\
\text { stream channel }\end{array}$ & $\begin{array}{l}\text { Channelling or dredging } \\
\text { absent or minimal; } \\
\text { stream with normal } \\
\text { pattern }\end{array}$ & $\begin{array}{l}\text { Presence of channelling, } \\
\text { usually near building } \\
\text { bridges; evidence of } \\
\text { changes for over } 20 \\
\text { years }\end{array}$ & $\begin{array}{l}\text { Modification present on } \\
\text { two margins; } 40 \% \text { to } 80 \% \\
\text { of the modified stream }\end{array}$ & $\begin{array}{l}\text { Cemented margins; over } \\
80 \% \text { of the modified } \\
\text { stream }\end{array}$ \\
\hline $\begin{array}{l}\text { Characteristics of } \\
\text { the flow }\end{array}$ & $\begin{array}{l}\text { Relatively equal flow } \\
\text { across the width of } \\
\text { the stream; Minimum } \\
\text { amount of exposed } \\
\text { substrate }\end{array}$ & $\begin{array}{l}\text { Water depth above } 75 \% \\
\text { of the stream channel; } \\
\text { or less than } 25 \% \text { of the } \\
\text { exposed substrate }\end{array}$ & $\begin{array}{l}\text { Water depth between } 25 \% \\
\text { and } 75 \% \text { of the stream } \\
\text { channel, and/or most of } \\
\text { the substrate in the "fast" } \\
\text { exposed }\end{array}$ & $\begin{array}{l}\text { Water depth sparse and } \\
\text { present only in the pools }\end{array}$ \\
\hline $\begin{array}{l}\text { Stability margins } \\
\text { (score for each } \\
\text { margin). }\end{array}$ & $\begin{array}{l}\text { Stable margins; minimal } \\
\text { or no evidence of } \\
\text { erosion; little potential } \\
\text { for future problems. Less } \\
\text { than } 5 \% \text { of the margin } \\
\text { affected }\end{array}$ & $\begin{array}{l}\text { Moderately stable; small } \\
\text { areas with erosion. } \\
\text { Between } 5 \% \text { and } 30 \% \\
\text { with margin erosion }\end{array}$ & $\begin{array}{l}\text { Moderately unstable; } \\
\text { between } 30 \% \text { and } 60 \% \\
\text { with margin erosion. High } \\
\text { risk of erosion during } \\
\text { floods }\end{array}$ & $\begin{array}{l}\text { Unstable; many areas with } \\
\text { erosion; frequent areas } \\
\text { uncovered in the stream } \\
\text { curves; erosion between } \\
60 \% \text { and } 100 \% \text { margin }\end{array}$ \\
\hline $\begin{array}{l}\text { Riparian } \\
\text { vegetation }\end{array}$ & $\begin{array}{l}\text { Width of riparian } \\
\text { vegetation }>18 \mathrm{~m} \text {; } \\
\text { without influence of } \\
\text { anthropogenic activities }\end{array}$ & $\begin{array}{l}\text { Width of riparian } \\
\text { vegetation between } \\
12 \text { and } 18 \mathrm{~m} \text {; minimal } \\
\text { anthropogenic activity }\end{array}$ & $\begin{array}{l}\text { Width of riparian } \\
\text { vegetation between } \\
6 \text { and } 12 \mathrm{~m} \text {; intense } \\
\text { anthropogenic activity }\end{array}$ & $\begin{array}{l}\text { Width of riparian vegetation } \\
\text { less than } 6 \mathrm{~m} \text {; restricted } \\
\text { or no vegetation due to } \\
\text { anthropogenic activity } \\
\text { (pastures, roads, etc.) }\end{array}$ \\
\hline
\end{tabular}

